the opportunity to train to spell, study lexical material, improve understanding of the audio text, develop reading techniques, learn grammar, train pronunciation [2].

Thus, at the present stage of development of science we can say for sure that the times when sufficient proof of language acquisition was the ability to translate from a foreign language and, conversely, adapted, non-authentic texts are over. In the context of high school reform, educational technologies for teaching foreign languages must also change. Involvement of modern technologies in the process of learning a foreign language significantly expands and diversifies the program, provides access to a variety of materials, expands students' motivation to learn, allowing them to work on the language at a pace convenient for them, thus individualizing learning and mastering a foreign language.

$* * *$

1. Chilingaryan, M. V. (2016) Ispol'zovaniye informatsionno-obrazovatel'nykh tekhnologiy na urokakh angliyskogo yazyka // Nauchno-metodicheskiy elektronnyy zhurnal «Kontsept». № S12. URL: http://ekoncept.ru/2016/76148.htm.

2. Hutchinson T., Waters A. English for Specific Purposes: A learning-centred approach. - Cambridge: Cambridge University Press, 2009. - 183 p.

3. Rieger, Caroline R. How (not) to be rude: Facilitating the acquisition of L2 (im)politeness // Intercultural Pragmatics. 2018. V. 15. Issue 5. Pp. 651-691

4. Romanova, G. V. (2016) Razvitiye inoyazychnoy grammaticheskoy kompetentsii obuchayushchikhsya 9kh klassov s uchetom ikh psikhologo-vozrastnykh i individual'nykh osobennostey (na osnove primeneniya interaktivnoy doski) // Pedagogicheskoye obrazovaniye v Rossii. № 2. S. 189-194.

5. Tsifrovaya transformatsiya obrazovaniya: sb. mat. 2-y Mezhd. nauch.-prakt. konf., Minsk, 27 marta 2019 g. / otv. red. A. B. Bel'skiy. - Minsk: GIATS Minobrazovaniya, 2019. - Rezhim dostupa: http://dtconf.unibel.by/doc/Conference_2019.pdf

\title{
Vorontsova U.A.
}

Forming and translating English neologisms in the software engineering field

Bryansk State Technical University

(Russia, Bryansk)

doi: $10.18411 / \mathrm{j}-06-2021-141$

\section{Abstract}

The article is devoted to defining the peculiarities and focus of translating English neologisms in the software engineering terminology. As part of the study the role of vocabulary is explored, the features of neologism derivations are classified; the main methods of their interpreting into Russian are examined, the ways of neologism word-building in the software engineering terminology are identified and the most frequent interlingual transformations used in conveying their meaning into Russian are determined. Results of the study reveal that the majority of neologisms are formed predominantly by stem-composition and affixation and the most common method of translating neologisms in the software engineering terminology is the loan-translation, transcription and translation method, grammatical substitutions and descriptive translation.

Keywords: software engineering, neologisms, translation transformations, translation, word-building.

\section{Аннотация}

Статья посвящена определению особенностей и направленности перевода английских неологизмов в терминологии программной инженерии. $\mathrm{B}$ статье проясняется роль лексики, анализируются особенности создания неологизмов, выделяются основные способы их передачи на русский язык, выявляются способы словообразования неологизмов в терминологии программной инженерии и определяются наиболее частотные переводческие трансформации, использованные при 
их передаче на русский язык. В результате исследования было выявлено, что большая часть неологизмов образована преимущественно путем словосложения и аффиксации, а наиболее типичным способом перевода неологизмов в сфере программной инженерии являются приёмы калькирования, транскрипции и транслитерации, грамматические замены, описательный перевод.

Ключевые слова: программная инженерия, неологизмы, переводческие трансформации, перевод, словообразование.

\section{Introduction}

Due to the rapid and continuous development of modern information technologies and engineering, changes, expressed in the occurrence of new words and word-combinations denoting new objects, terms, phenomena and concepts have taken place in the English language. Even the latest editions of Longman Dictionary of Contemporary English, Webster's Dictionary, Macmillan English Dictionary and others frequently lack this information. Hence, the field of computer engineering has become a rich source of neologisms that deserve special attention, since their interpreting often causes considerable difficulties and requires a more extensive study because if several words or combinations are incorrectly interpreted, the semantic load of larger units of the text may become irrelevant, which may lead to bad mistakes due to misunderstanding between the author and the reader.

It is necessary to identify the patterns that are observed when translating newly formed words from the computer engineering sphere from English into Russian considering that a distinguishing feature of English informational and technical material is a great use of terms, formulae, graphs, and the main task of translating such neologisms is a concise and accurate presentation of information and the absence of practically any intensifiers.

\section{Problem statement}

The term "software engineering" first appeared in 1968 and 1969 when the NATO Science Committee sponsored two conferences on software engineering. The aim of those conferences was to stimulate the search for solving the so-called "software crisis", which identified many of the software development problems. Conducting those conferences gave the field its initial boost and marked the official start of the profession. Software engineering provides significant support for humanity in various fields of medicine, security and process optimization. Technical texts in the software engineering filed are characterized by the fact that the subject information is more important in them than the language knowledge, which, in turn, must first and foremost lead to mastering special terms [8]. This peculiarity requires from the translator to be proficient in the covered technical and computer science field, to analyse the meanings the word can have in the context, in contrast to those given in the dictionaries and consider basically extralinguistic information.

So, the first step of interpreting the neologisms in the software engineering field is to analyse the meaning of a new concept, focus on the equivalents and determine which concept the term expresses depending on the area of use and context [2, p. 40].

Linguists from Russia define "neologisms" as the words and expressions representing both language units that have become relevant in a specified time period [3], [5]. However, in this article we will share the position of the German linguist D. Gerberg who believes that a word is a neologism if: "...its form and content, or only the content at some point of time and for a certain time is perceived by the majority of native speakers as new" [11, p. 74]

\section{Ways of neologism formation}

Before exploring the ways of translating neologisms [6], [7], [9] one should consider the ways of forming these lexical units.

1. Affixation is a common productive way of word derivation, forming new words from morphemes existing in the language according to such methods as: suffixation, prefixation or a prefix-suffix [3]. The noun "digitalization" is formed by adding the suffix "tion" to the verb "digitalize". The noun "cyberlocker" meaning an internet service allowing users to store and share files online is formed by a prefix-suffix method adding the prefix 
"cyber-" and suffix "-er" to the stem of the noun "lock", the nouns "cyberbullying" or "cyberabuse" meaning communication by electronic means for the purpose of people's intimidation or threats, "cyberstalking" referring to the virtual harassment, pursuing or monitoring of someone are formed by a prefix-suffix method adding the prefix "cyber-" and suffix "-ing" to the stems of the nouns "bully", "abuse" and "stalk". The term "antivirus" meaning a programme that detects a virus in the computer memory and neutralizes its action, is formed with the help of the prefix "anti-" and a noun "virus", the term "plugin" meaning a software module that extends the main application functionality is formed by adding the noun "plug" and the preposition "in".

2. Compounding or stem-composition is also a productive way of word derivation formed by combing two or several stems to render one word [3]. So, the noun "bitcoin" denoting an Internet currency is formed as a result of adding two simple stems "bit" and "coin". The word "chatbot" meaning software that can allow conducting online chat conversations and interacting with people via messaging platforms is obtained in the same way by adding two simple stems "chat" and "bot". The terms "firewall" meaning a programme for protecting computer networks, "framework" indicating the structure of a software system, that exposes developing and integrating different components of a large software project, "newsgroup", "username", "password" can serve as examples of forming new terms using the way of compounding or stem-composition. These terms are formed by merging the stems "fire" and "wall" ("firewall"), the noun stems "frame" and "work" ("framework"), the nouns "news" and "group" ("newsgroup"), the stems "user" and "name" ("username"), the verb stem "to pass" and the noun stem "word" ("password"). Similar examples are "blockchain technologies" meaning a distributed storage of relevant records, this word-combination is formed by adding two stems "block" and "chain" and the word "technology", "broadband" indicating a system that allows many messages to be sent simultaneously and fast between electronic devices, is formed from two stems "broad" and "band", "databases" is derived from two stems "data" and "base", "bulletproof" meaning a programme that is capable of handling any emergencies in the Net, is formed from two stems "bullet" and "proof". The same tendency is seen on the terms "ironmonger" meaning electronics engineer, "wirehead" denoting a person who works in the Net, they are built by adding the stems "iron" and "monger" and "wire" and "head", respectively.

3. Conversion is a process of forming a new grammatical utterance in a various speech part without any changes in spelling or pronunciation; it is also called an affixless derivation or zero-suffixation. For example, the verbs "to facebook" and "to google" are formed as a result of their noun conversions, i.e. "Facebook" and "Google", respectively. More instances include "to browse", "to chat", "to message", "to broadcast" which are built as a result of the conversion of their own nouns "browse", "chat", "message", "broadcast".

4. Acronyms are pronounceable words formed from the first letter or few letters of each word in a phrase or title. Acronyms are widely used in English [3]. For example, neologism " $2 F A$ ", denoting an extra layer of protection used to ensure the security of online accounts beyond just a username and password, is formed from the original phrase "twofactor authentication". In this case, instead of the word "two", the symbolic designation " 2 " is used. Some more instances include: "IP" which is formed from the original phrases "Global Internet Protocol" or "Intellectual Property", "GB" built from "gigabytes", "ICT" derived from "the Information and Communications Technology", "IoT" formed from "the Internet of things", " $3 D$ printing" formed from "three-dimensional printing", " $5 G$ " formed from "The fifth generation", "AI" formed from "Artificial intelligence", "IXPs" built from "Internet exchange points", "UI" derived from "The User Interface".

5. Reductions or compressions are shortening the words, the so-called "lexical summary", i.e. converting a phrase into a word when the duplication of redundant semantic components is eliminated. Reductions or compressions are typical for English [3]. The example is the neologism "site" which is the result of an initial truncation of the term 
"Website". It is also worth noting that several ways of the word derivation can simultaneously be present in one word or expression. For instance, the word "Weblog" is formed by a reduction of the noun "blog", and "blogger" is formed by using an affix "-er", the word "netizen" meaning an Internet user who spends a lot of time on the Internet, is formed by combining the compression of the noun "network" and a reduction of the noun "citizen", "phablet" meaning a smartphone that is larger than the screen of the conventional smartphones but smaller than a tablet, is a term formed from merging the first letters of the word "phone" and a reduction of the noun "tablet".

6. Semi-reductions are a specific English subtype of reductions [3]. Examples of semi-reductions include terms such as "e-mail" or "e-commerce", "e-retailer", "elearning", "e-signature", "e-book". Here the acronym " $e$ " meaning "electronic" is combined with the full stems of the words "mail", "commerce", "retailer", "learning", "signature", "book", respectively.

7. Secondary nomination is the result of derivational processes of using an already existing name for the second time to denote another meaning [3]. For example, at present in the context of software engineering the noun "viewer" means a programme designed to view but not modify files in a certain format, the word "informer" means a type of malware that displays advertisements on the desktop, the word "swapping" means exchanging something, replacing one programme segment in the computer memory with another and restoring it on demand. Some more instances include "digital hangover" denoting a person's feeling of shame as he had a great fun at a party the day before, and today observes "compromising" on the Internet, "pain in the net" meaning "a network brawler", a net user having a bad reputation, "game changer" translated into Russian as "a turning point", supposing a new element that radically and dramatically changes the situation on the Internet.

All methods of neologism formation are summarized in diagram 1.

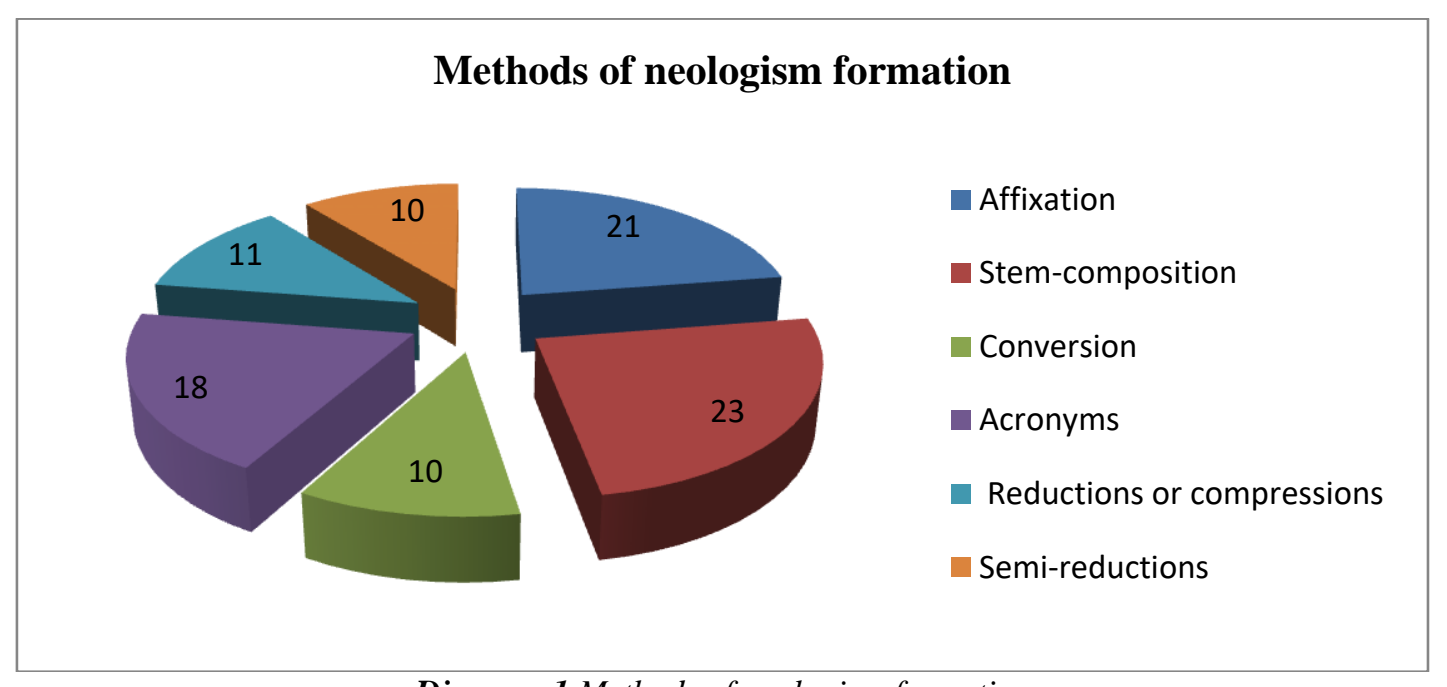

Diagram 1 Methods of neologism formation

Diagram 1 shows that the most frequent methods of neologism formation are stemcomposition (23\%) and affixation (21\%), but other methods of neologism formation are rather frequently used.

\section{Ways of neologism translation}

Translation is a type of activity in which a text generated in one language is converted into a text in another language [1]. The translation process can be depicted in different ways, and the most vivid of them is conveying the interpreting process using linguistic transformations. According to V.N. Komissarov, translation (interlingual) transformations are transformations by means of which it is possible to carry out a transition from the source units to the target units $[4$, p. 38]. 
In foreign and domestic translation studies, in those numerous cases where there is no equivalent translation, different types of transformations are used when translating neologisms in the computer and programme engineering sphere from English into Russian, namely translation transcription, translation transliteration, loan translation, grammatical substitutions descriptive translation.

1. Translation transcription is transferring the sound form of the word by the target language means. Vivid and most frequently used examples are "bitcoin", "lootbox", "startup", "mash-up" which are respectively interpreted as «биткоин», «лутбокс», «cmapman» and "мэщаn". Another example is neologism "ICQ”, meaning a programme for instant messaging ICQ which is translated into Russian as a slang word "ACЯ». The following sentence also colorfully depicts this tendency: There will not be loot boxes, and there will not be Pay-to-Win types of microtransactions [10]. - Здесь не будет ни лутбоксов, ни каких-либо донатных видов. In some cases, when applying this technique, the original terms are somewhat assimilated to the linguistic norms of the target language. For example, the term "to upgrade" is translated as «апгрейдить», the verb "to game" is often interpreted as a barbarism "гаймить" and the neologism "to mine" is translated as a slang verb «майнить», for instance: One day I decided to Google how profitable it is to mine in 2021 [10]. - В один прекрасный день я решил погуглить, насколько выгодно майнить в 2021 году.

2. Translation transliteration is transferring a graphic form or a letter structure of the word from the original language by means of the target language. The examples of this type include the nouns "servent" indicating a programme that runs on the server and extends the web server functionality, translated into Russian as «сервент», the term "Telex" denoting an international subscriber telegraph communication carried out by means of a telephone network, interpreted into Russian as "Телекс», "crack" indicating a software hacking programme translated into Russian as «крэк», "blogger" - «блогер», "hypervisor" meaning computer software that develops and runs virtual machines, translated into Russian as «гипервизор».

3. Loan translation is borrowing foreign words, expressions, phrases by literal translation of the corresponding linguistic units, as well as the result of these borrowings in the form of words, expressions and phrases [3]. This technique is used in such neologisms as "2FA" (two-factor authentication) - «двухфакторная аутентификация», "cloud architecture" - «облачная архитектура», "three-dimensional (3D) printing" трехмерная (3D) печать, "The fifth generation (5G) wireless technology" - «беспроводная технология пятого поколения (5G)», "software engineering” - «программная инженерия».

4. Grammatical substitutions being the most widely-used and heterogeneous type of transformations and showing the change of the grammatical category of the translated unit are necessary due to the specificity of the English and the Russian languages [1]. For example, when translating the phrase "facial recognition" - «распознавание лии», the adjective "facial" (лицевой) is replaced with a plural noun in the genitive case "persons" (лиц), while translating the neologism-idiom "pain in the net" - «сетевой скандалист» the noun "pain" (боль) is replaced with a noun "brawler" (скандалист) and the prepositional noun "net" (сеть) is translated as an adjective «сетевой». In the following instance "game changer" - «переломный момент» we see that the noun "changer" (игра) is translated as the adjective «переломный».

5. In the occasions when the translator fails to find an equivalent or adequate term or word for the correct and literate interpretation, the technique of descriptive translation is applied. So the term "firmware" is interpreted as «программы, записанные в постоянное 
запоминающее устройство», the term "middleware" is described as "связующее программное обеспечение», the phrase "a turning point" is interpreted as «новый элемент, который в корне меняет ситуацию в Интернете», the phrase "Guerilla proofreading” is translated as "дотошное выискивание ошибок в тексте сообщений и затем публичное указание на них" [9].

So, all translation transformations used in conveying the meaning of the neologisms in the computer engineering field are summarized in diagram 2.

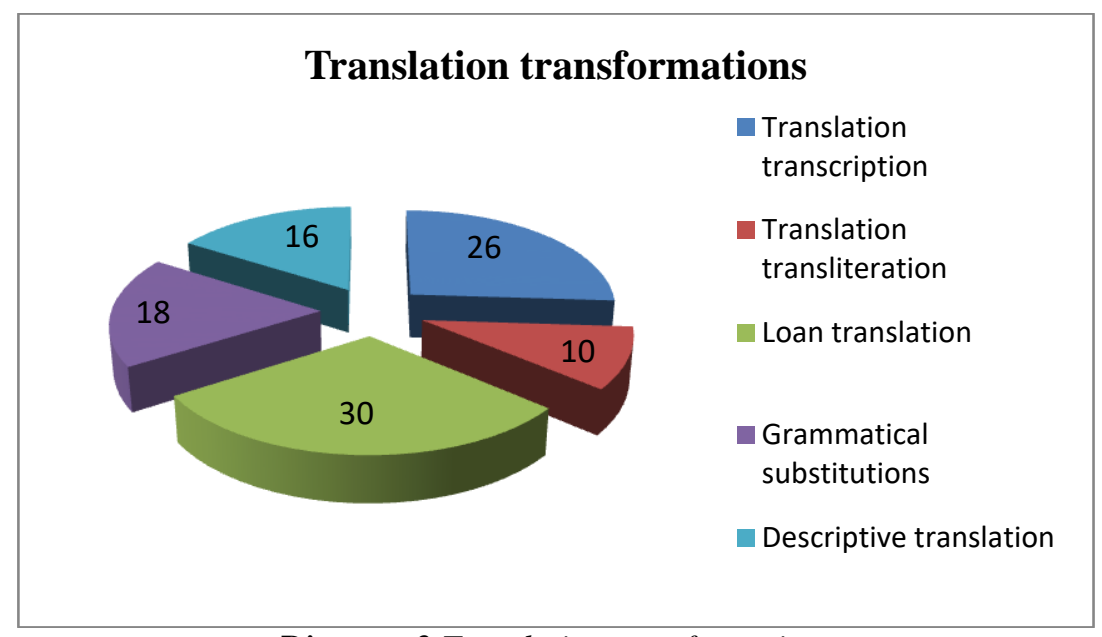

Diagram 2 Translation transformations

Diagram 2 shows that the most frequent transformations are loan translation (30\%) and translation transcription $(26 \%)$. The frequency of loan translation and translation transcription is explained by the fact that the target language has lexical units with similar semantics, due to which it is possible to preserve the neologism meaning and not to have linguistic borrowings.

\section{Conclusion}

Thus, studying English neologisms in the field of programming engineering terminology has made it possible to identify the trends in their word-building and to single out some translation strategies. The methods of forming neologisms largely determine the choice of their translation methods. So, the most characteristic ways of forming English neologisms in the field of programming engineering are stem-composition and affixation.

Analysing the methods of translating English neologisms in the computer engineering field allows concluding that new formations are reflected in the modern English language and neologisms are increasingly being introduced into the human speech, replacing other words. More frequently English neologisms in the field of programming engineering are translated by the method of loan translation and translation transcription. Applying descriptive translation is mainly associated with the recipients' poor background knowledge in this particular area, which requires discovering the meaning of the lexical units used in the source language while grammatical transformations are necessary to convey the corresponding forms and structures due to some discrepancies in their meaning and use in the English and Russian languages.

$$
* * *
$$

1. Воронцова Ю.А. Grammatical transformations in translating adverbial clauses of time (Based on the English language) // Вестник Северного (Арктического) федерального университета. Серия: Гуманитарные и социальные науки. 2019. №5. URL: https://cyberleninka.ru/article/n/grammaticaltransformations-in-translating-adverbial-clauses-of-time-based-on-the-english-language (дата обращения: 08.05.2021).

2. Дмитриева Л. Ф., Кунцевич С. Е., Мартинкевич Е. А. Английский для студентов. Курс перевода. M.: MapT, 2005. 304 c. 
3. Киева О. В. Перевод компьютерных неологизмов в материалах научно-технического жанра // Символ науки. 2016. №4-3. URL: https://cyberleninka.ru/article/n/perevod-kompyuternyh-neologizmovv-materialah-nauchno-tehnicheskogo-zhanra (дата обращения: 04.05.2021).

4. Комиссаров В.Н. Лингвистика перевода: [монография]. М.: ЛИБРОКОМ, 2009. 165 с.

5. Мирзамова А. С. Перевод английских неологизмов в современных экономических текстах // Филологические науки. Вопросы теории и практики. 2020. №6. Available at: https://cyberleninka.ru/article/n/perevod-angliyskih-neologizmov-v-sovremennyh-ekonomicheskihtekstah (дата обращения: 08.05.2021).

6. Неологизмы в сфере информационных технологий. - URL: https://scienceforum.ru/2016/article/2016018601 (дата обращения: 08.05.2021).

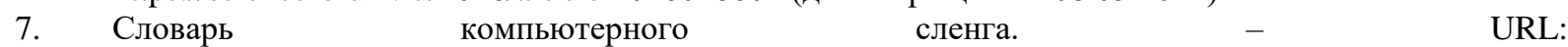
https://www.sites.google.com/a/ssga.ru/ssga4school/informatika/glossary/glossary-slang (дата обращения: 08.05.2021).

8. Чайко, А. А. Трудности перевода английского языка / А. А. Чайко, Ю. А. Воронцова // Многоязычие и поликультурное образовательное пространство в России: современные тенденции: Материалы III Всероссийской очно-заочной студенческой научно-практической конференции, Орел, 07-14 апреля 2020 года. Орел: Орловский государственный университет имени И.С. Тургенева, 2020. С. 420-423.

9. Шушарина Г.А. Способы перевода неологизмов в терминологической системе компьютерных технологий // Вестник ЧелГУ. 2019. №1 (423). URL: https://cyberleninka.ru/article/n/sposobyperevoda-neologizmov-v-terminologicheskoy-sisteme-kompyuternyh-tehnologiy (дата обращения: 04.05.2021).

10. Coetsee J. Metal Gear Survive Producer Confirms No Lootboxes And Pay To Win Microtransactions, 2018. Available at https://gameranx.com/updates/id/135721/article/metal-gear-survive-producerconfirms-no-lootboxes-and-pay-to-win-microtransactions (accessed 08 May 2021).

11. Herberg D. Neuer Wortschatz Neologismen der 90-er Jahre im Deutschen. / D. Herberg. Berlin: Walterde Gruyter, 2004. 393 S. 